\title{
MENDARAS AJARAN KRISTIANITAS KRISTUS DI TENGAH PANDEMI: MENGUNGKAI SEMANGAT MELAYANI
}

\author{
Oleh: Maria Yulita C. Age
}

\begin{abstract}
Abstrak
Mendaras ajaran kristianitas di tengah pandemi dapat dicontohi melalui sikap pelayanan Yesus. Penelitian ini bertujuan agar di tengah pandemi manusia dapat mencontohi Yesus sebagai pelayan dan pengajar. Pendekatan penelitian yang digunakan adalah pendekatan kualitatif. Hasil penelitian menunjukkan bahwa dengan situasi ini ajaran kristianitas mengajarkan agar manusia menyimpulkan bagaimana Yesus menginginkan dan memberikan contoh kepada para murid dan rasul awam sebagai pengikut-Nya untuk selalu hidup dalam kerendahan untuk melayani orang lain sebagai pelayan dan pengajar. Untuk menjadi pelayan, seseorang harus belajar dan menumbuhkan sikap rendah hati, walaupun sebagai manusia seseorang tidak akan mungkin sama seperti Yesus tapi sebenarnya siapa pun dapat belajar menjadikan dirinya contoh seperti yang Yesus lakukan dalam melayani orang banyak ketika Ia masih hidup. Manusia patutlah menjadikan Yesus sebagai contoh dan panutan hidup dalam hal melayani, semangat melayani yang diajarkan Kristus patutlah diejawartakan dalam kehidupan sehari-hari.
\end{abstract}

Kata-kata kunci: Kristianitas, Pandemi, Semangat Melayani.

\section{A. Pendahuluan}

emangat pelayanan kristianitas dewasa ini dapat diteladani melalui ajaran Yesus. Konsep melayani adalah konsep yang mewarnai pribadi hamba Allah. Konsep ini diperkuat dengan apa yang Yesus ucapkan ketika permintaan Yakobus dan Yohanes untuk duduk dalam kemuliaan Allah kelak, yang seorang di sebelah kanan dan yang seorang lagi di sebelah kiri. Sebuah permintaan yang sulit dan tidak dapat dipenuhi begitu saja. Yesus dengan tegas menjawab: "Tetapi barang siapa yang ingin menjadi besar diantara kamu, hendaklah ia menjadi pelayanmu, dan barangsiapa ingin menjadi terkemuka di antara kamu, hendaklah ia menjadi hamba untuk semuanya" (Mrk. 10:3545). ${ }^{1}$ Sebenarnya, yang Yesus tegaskan ini menunjukkan bahwa Yesus menginginkan dan memberikan contoh kepada para murid sebagai pengikut-Nya untuk selalu hidup dalam kerendahan untuk melayani orang lain. Menjadi pelayan juga harus belajar dan menumbuhkan sikap rendah hati, belajar dari Yesus walaupun sebagai manusia seseorang tidak akan mungkin sama seperti Yesus tapi sebenarnya siapa pun dapat belajar menjadikan dirinya contoh seperti yang Yesus lakukan dalam melayani orang banyak ketika Ia masih hidup. ${ }^{2}$

Oleh karena itu, di tengah situasi pandemi ini untuk melakukan semuanya mesti ada aksi yang ditunjukkan yakni perbuatan nyata yang dalam hidup sehari-hari bukan hanya

\footnotetext{
${ }^{1}$ Stefan Leks, Tafsir injil Markus, (Yogyakarta: Kalam Hidup, 2007), hlm. 362.

${ }^{2}$ St. Darmawijaya, Gelar-gelar Yesus, (Yogyakarta: Kanisius, 1991), hlm. 103-104.
} 
sebuah perkataan yang keluar dari mulut masing-masing orang. Sebab hal ini juga yang dilakukan Yesus ketika Ia berada di dunia.

Pelayanan yang Yesus lakukan adalah melayani tanpa pandang bulu, entah itu anak kecil, orang muda, dan orang tua, laki-laki atau perempuan. Ia bahkan menunjukkan perhatian yang mendalam kepada mereka yang benar-benar membutuhkan pelayanan dariNya yakni orang miskin dan kekurangan, orang-orang lemah dan tertindas, mereka yang termarginalkan dalam masyarakat secara sosial, sampai pada mereka yang kena sakit kusta yang dikucilkan dalam masyarakat bahkan dijauhkan dari pemukiman rakyat karena dianggap mendatangkan kutuk pun, Yesus layani dengan tidak bersungut dan merasa najis dan kotor tangan-Nya. Bahkan mereka inilah yang Yesus prioritaskan dalam pelayananNya untuk segera dilayani mendahului mereka yang lain. Sering sekali seperti yang diceritakan dalam kitab-kitab Injil bahwa murid-murid Yesus sendiri bahkan pernah melarang orang-orang untuk tidak berbondong-bondong dan membuat Yesus kelelahan karena Yesus pun memerlukan istirahat, tetapi Yesus bahkan tidak pernah mengahalanghalangi orang banyak untuk datang mendapatkan pelayanan dari-Nya. Yesus sendiri pun tidak pernah membiarkan orang-orang yang membutuhkan pelayanan-Nya, walaupun sebagai manusia juga Ia merasa kelelahan berjalan seharian melakukan pelayanan, namun patut dipelajari oleh pelayan Gereja bahwa semua itu tidak membuat-Nya berhenti untuk tidak melayani.

Hal ini sebenarnya menunjukkan bahwa Yesus sebagai manusia biasa yang penuh dengan keterbatasan benar-benar memaknai panggilan-Nya sebagai pelayan yang penuh kasih untuk melayani semua orang yang datang, juga menunjukkan bahwa Ia adalah sosok seorang hamba yang melayani dengan kasih yang tak terbatas, bahkan kasih itu ditunjukkan-Nya pada pengorbanan di salib. Dewasa ini semangat pelayanan makin merosot, banyak yang memberikan pelayanan karena ada maksud tertentu atau karena ada kepentingan pribadi dan lain sebagainya. Sitausi yang saat ini dalam keterbatasan akibat merebaknya virus corona menuntut setiap orang yang bergerak di bidang pelayanan harus mampu mengambil sikap dan mewujudkan bentuk pelayanan yang baik seperti yang diajarkan oleh Yesus dalam tindakan nyata yang terdapat dalam Injil. Oleh karena itu, dalam uraian ini akan dipaparkan bagaimana ajaran kristianitas Kristus dalam melayani di tengah pandemi.

\section{B. Metode}

Jenis penelitian ini adalah penelitian kualitatif deskriptif, yaitu data yang dikumpulkan berbentuk kata-kata, gambar, bukan angka-angka. ${ }^{3}$ Menurut Bogdan dan Taylor, sebagaimana yang dikutip oleh Lexy J. Moleong, penelitian kualitatif adalah prosedur penelitian yang menghasilkan data deskriptif berupa kata-kata tertulis atau lisan dari orang-orang dan perilaku yang diamati. ${ }^{4}$ Sementara itu, penelitian deskriptif adalah suatu bentuk penelitian yang ditujukan untuk mendeskripsikan atau menggambarkan fenomenafenomena yang ada, baik fenomena alamiah maupun rekayasa manusia. ${ }^{5}$

${ }^{3}$ Sudarwan Danim, Menjadi Peneliti Kualitatif Rancangan Metodologi, Presentasi, dan Publikasi Hasil Penelitian untuk Mahasiswa dan Penelitian Pemula Bidang Ilmu Sosial, Pendidikan, dan Humaniora, (Bandung: Remaja Rosdakarya, 2002), hlm. 51.

${ }^{4}$ Lexy. J. Moleong, Metodologi Penelitian Kualitatif, (Bandung: PT Remaja Rosdakarya, 2018), hlm. 3.

\footnotetext{
${ }^{5}$ Ibid., hlm. 17.
} 


\section{Pembahasan}

Gereja sebagai persekutuan kudus yang lahir di dalam dunia melaksanakan amanat Yesus Kristus demi pertumbuhan dan perkembangan Gereja itu sendiri ${ }^{6}$. Seiring dengan perkembangan zaman, Gereja dituntut untuk sanggup mengkaji dan merencanakan langkah-langkah yang perlu ditempuh untuk mencapai kondisi yang diharapkan dalam pelayanan terhadap umat-Nya. Untuk dapat melayani efektif maka seorang pelayan yang juga adalah seorang pemimpin perlu memiliki dan menyadari motivasi yang dimilikinya. Situasi pandemi saat ini membutuhkan banyak pelayan yang mampu bekerja tanpa pamrih dengan semangat melayani tanpa pandang buluh dan semangat melayani dengan ketulusan dan cinta kasih. Ketakutan akan penyebaran virus yang semakin meluas membuat semangat melayani menjadi kendor. Segala bentuk pelayanan dibatasi dan bahkan ditutup, sehingga banyak keluhan akibat situasi yang tidak pernah diketahui kapan berakhir.

\section{Yesus Sebagai Pelayan}

Pengertian pola menurut Kamus Besar Bahasa Indonesia adalah "gambar yang dipakai, model, sistem, cara kerja, bentuk atau struktur yang tetap. ${ }^{7}$ Pola pelayanan adalah gambaran atau cara kerja pelayanan yang dilakukan. Istilah pelayanan yang sering terdengar adalah service. Pelayanan ini dibidang bisnis dan jasa umum atau transportasi yang melayani bukan tanpa pamrih. Dalam Kamus Besar Bahasa Indonesia, melayani berasal dari kata layan menjadi melayani artinya orang yang pekerjaannya melayani, pembantu $^{8}$, jadi pelayanan berarti berusaha melayani kebutuhan orang lain dengan memperoleh imbalan. Semangat melayani dalam ruang lingkup kristianitas di tengah pandemi ini dapat dicontohi melalui sikap Yesus sebagai pelayan dan guru. Hal ini ditunjukkan dari sikap Yesus yang senantiasa melayani tanpa membedakan orang, tanpa takut penyakit yang akan menyerang maka Ia menyembuhkan orang dengan berbagai penyakit, tanpa membedakan jenis kelamin, kaya atau miskin, atau tanpa membedakan apabila murid Yesus maka akan dilayani sedangkan apabila bukan tidak akan dilayani. Jadi, meneladani sikap Kristus dengan semangat pelayan perlu diaplikasikan di tengah situasi pandemi.

Pada umumnya pelayanan diartikan sebagai ibadah, kegiatan spiritual, dan kegiatan ritual keagamaan ${ }^{9}$. Pelayanan yang sebenarnya dapat dilihat dalam pola pelayanan-Nya yang holistik. Yesus menerapkan cara hidup dan pelayanan dengan menyuarakan kebenaran. Kedekatan Yesus dengan Bapa-Nya melahirkan kepedulian dan kritis terhadap kehidupan manusia dan ciptaan lainnya. Kedekatan dengan Tuhan membuat pelayan berani untuk pergi menjadi saksi-saksi yang hidup, baik di dalam persekutuan maupun dunia pada umumnya. Penyerahan diri total kepada Yesus menjadi syarat untuk mengikuti kehendak Allah, sehingga pelayan mampu melayani tanpa pamrih.

Dalam pelayanan-Nya, Yesus mengajar dan menyembuhkan dari kota ke kota. Tuhan Yesus mengetahui cara menghadapi setiap orang dengan metode yang berbeda. Pelayanan Yesus menerapkan metode sesuai dengan keadaan yang dihadapi orang misalnya perempuan yang kedapatan berzinah, Yesus memberi pengampunan (Mat. 19:13$15)^{10}$. Ketaatan Yesus yang total kepada Allah yang membuat-Nya secara eksistensial dan total pula menaruh kepedulian kepada umat manusia dan seluruh ciptaan. Yesus

${ }^{6}$ Nico D. Syukur, Kristologi sebuah Sketsa, (Yogyakarta: Kanisius, 1987), hlm. 24.

${ }^{7}$ Depdikbud, Kamus Besar Bahasa Indonesia (Edisi 5), (Jakarta: CV Adi Perkasa, 2018), hlm. 1300.

${ }^{8}$ Ibid., hlm. 952.

9 Abineno, J.L Ch., Pedoman Praktis Untuk Pelayanan Pastoral, (Jakarta: BPK Gunung Mulia, 2006), hlm. 12.

${ }^{10}$ Gunche Lugo, Manifesto Politik Yesus, (Yogyakarta: Penerbit ANDI, 2009), hlm. 42. 
mengungkapkan secara implisit bahwa, jalan menuju kebenaran adalah jalan pelayanan. Dia sendirilah pola dan gambar yang dasariah dari pelayanan.

Yesus sangat mementingkan hubungan intim dengan Allah Bapa. Ia memahami persis pikiran, perasaan dan kehendak Bapa-Nya. Dalam segala waktu dan tempat Ia berkomunikasi dengan Allah Bapa. Ia mendahulukan kepentingan Allah melebihi segalagalanya. Yesus melihat manusia sebagai citra Allah pula. Ia sangat menghargai dan mencintai sesama manusia. Pengenalan akan diri bagi pelayan harus menyadari bahwa ia mudah marah atau tiba-tiba merasa takut. Orang percaya hendaknya meneladani Yesus dalam aspek horisontalnya. Dalam lingkungan kehidupan Kristen, pelayanan paling banyak dipakai sehubungan tugas di dalam Gereja di samping kata mengasihi atau kasih yang menjadi penekanan ajaran.

\section{Yesus Sebagai Pengajar}

Kehadiran Yesus di dunia dikenal dengan inkarnasi yang berarti Allah mengambil rupa manusia secara utuh sama dengan manusia, bahkan mengambil rupa seorang hamba (Flp. 2:5-8). Dengan keberadaan sebagai manusia sederhana, Ia turut merasakan keberadaan manusia yang sesungguhnya. Yesus menjadi Juruselamat yang utuh secara rohani dan jasmani. Yesus berkeliling ke semua kota dan desa; Ia mengajar dalam rumahrumah ibadat dan memberitakan Injil Kerajaan Surga serta melenyapkan segala penyakit dan kelemahan (Mat. 9:35).

Wewenang Yesus sebagai pengajar nyata dari pernyataan-Nya. Wewenang itu nyata pula dalam perbuatan kasih-Nya bagi banyak orang. Dia mengajar atas dasar Firman Allah serta secara cakap membaca hati orang-orang yang dihadapi-Nya. Yesus dalam menghadapi murid-murid-Nya dengan latar belakang yang berbeda. Yesus sebagai pribadi yang mengajar secara terus terang dengan tujuan yang jelas pula. Tujuan Yesus dalam mengajar ialah membentuk cita-cita luhur dalam diri para murid-Nya, membentuk keyakinan yang teguh, memiliki hubungan dengan Allah dan sesamanya. Para murid didorong-Nya agar kreatif menghadapi masalah hidup sehari-hari dan memiliki watak yang bagus dalam menjalankan tugas pelayanan. Pengajaran Yesus berhasil dalam rangka mengangkat derajat para murid, mengubah kehidupan mereka agar percaya kepada-Nya.

Yesus senantiasa menyesuaikan pengajaran-Nya. Dia menyentuh suara hati mereka serta merangsang mereka untuk aktif berbuat. Bahan pengajaran Yesus diambil dari Perjanjian Lama diintegrasikan dengan peristiwa alam dan peristiwa yang hangat yang sedang terjadi. Dia menggunakan pepatah, ilustrasi, perumpamaan dalam memulai atau dalam menjalankan pengajaran. ${ }^{11}$ Pengajaran Yesus amat menarik, diawali pendahuluan, isi dan kesimpulan. Kebergantungan Yesus yang amat sempurna kepada Allah Bapa itu mewarnai pola pikir dan sikap seseorang jika ingin berhasil dalam tugas mengajar atau mendidik. Selain itu, teladan Yesus sebagai manusia sejati yang rela belajar, harus mendorong orang percaya untuk rela berlatih, belajar mengembangkan diri dalam karunia yang Allah berikan guna mengajar orang lain. Yesus berkarya atas dasar tujuan yang jelas, yakni membina murid agar mengerti serta mengalami kekudusan Allah. Murid diajar-Nya agar menyadari diri sebagai hamba. Murid pun diajar agar hidup dalam relasi kasih dengan sesamanya. Sebagai hamba yang melayani sesama, serta mengarahkan mereka berdamai dengan Allah.

Cara Yesus melaksanakan tugas-Nya sebagai guru amat mengagumkan. Yesus memang unik namun Dia menjadi sama dengan murid-murid-Nya dan dengan orang-orang lain yang dilayani-Nya. Dia membaca apa kebutuhan mereka, pergumulan serta tingkat

\footnotetext{
${ }^{11}$ Robert R. Boehlke, Siapakah Yesus Sebenarnya, (Jakarta: BPK Gunung Mulia, 2001), hlm. 23-24.
} 
pengertian mereka. Dia "menjadi satu" dengan berita yang disampaikan. Tidak heran mengapa Yesus begitu berotoritas. Hal itu tampak dalam pernyataan-Nya: "Aku berkata kepadamu..." atau "Aku adalah..." teladan Yesus dalam kerelaan menjadi sama dengan orang yang dilayani dan perkara yang berkembang dalam hati seorang guru jika ia hendak membawa pembaruan ${ }^{12}$.

Yesus mengarahkan murid mencapai target dalam hal apa yang diperbuat mereka. Artinya, relasi tidak hanya sebatas kata, ucapan dan peristiwa sewaktu-waktu. Dalam mengajar, Yesus membuat murid-murid aktif dan senantiasa di dalam keaktifan, apakah berpikir, merasa dan memberi respons serta berbuat. Dia pun mengajar melalui perbuatan nyata seperti mujizat, diskusi dan tanya jawab. Dia senantiasa memberi dorongan untuk bertindak. Teladan Yesus mendasari nilai hidup dan pemikiran pelayan. Perbuatan mendidik maupun mengajar, pelayan menekankan kebersamaan, keaktifan dengan tujuan jelas.

Menyikapi situasi yang semakin memanas dengan pertambahan jumlah penderita virus yang dapat mematikan ini seorang pelayan dituntut mempunyai hati yang rela berkorban, meskipun menghadapi kesulitan juga tidak akan meninggalkan dan membiarkan domba-dombanya. Ia mengenal setiap dombanya, juga bersedia membawa domba yang berada di luar, menyediakan dan mencukupi segala kebutuhan dombanya, termasuk kebutuhan intelektual, emosi, mental, dan rohani. Sebagai hamba Tuhan, setiap pelayan sudah selayaknya memikirkan pelayanan secara utuh, sebab pemikiran, saran, dan ide-idenya sangat dibutuhkan dalam setiap bidang pelayan sesuai dengan pekerjaan yang diemban saat ini. Pelayanan terhadap manusia sesuai dengan konteks keberadaan orang yang dilayani. Yesus dengan setia memenuhi panggilan Bapa-Nya, meskipun panggilan tersebut berakhir pada siksaan dan kematian. Meskipun Tuhan Yesus memahami bahwa kematian-Nya sudah dekat, namun Ia tetap giat di dalam pelayanan-Nya. Ia berkeliling kota dan desa untuk mengajarkan Injil Kerajaan Allah. Panggilan pelayanan bukanlah pengalaman sekali seumur hidup melainkan merupakan tanggapan murid yang berkelanjutan. Yesus juga menunjukkan betapa Ia tidak membeda-bedakan pelayanan.

Pelayan sebagai manusia memiliki konsep diri yang positif dan nilai diri yang mendasar agar pelayanan menjadi sehat dan baik. ${ }^{13}$ Orang yang dipanggil menjadi pelayan selalu hidup dalam ketegangan antara watak dan kekurangan mereka serta tuntutan panggilan mereka. Prinsip pelayanan yang berlaku adalah memperhatikan kesehatan untuk meraih hidup dengan sukacita. Kerendahan hati adalah guru yang hebat jika dikembangkan dengan maksimal.

Pekerjaan Yesus yang paling banyak adalah menyembuhkan dan kehadiran-Nya bagi orang banyak. Untuk hal itu, Yesus tidak pernah melayani diri-Nya sendiri. Yesus kemudian mengatakan "Kamu adalah saksi dari semuanya ini" (Luk 24:47-48), dan "kamu akan menjadi saksi-Ku di Yerusalem dan di seluruh Yudea dan Samaria dan sampai ke ujung bumi" (Kis 1:8). Pernyataan ini menunjukan bahwa Yesus ingin mengajak semua hamba Allah agar tidak perlu merasa takut atau cemas sebab segala penyakit dapat disembuhkan seperti yang Ia lakukan kepada banyak orang.

Pelayan adalah orang yang melayani dan peziarah iman. Kunci pelayanan yang efektif adalah pertumbuhan yang berkelanjutan pada diri pelayan. Menurut Maggay, Yesus mengirim para murid untuk melayani, instruksi-Nya mengandung dua komponen yaitu; pertama, proporsional, "Bertobatlah, karena Kerajaan Allah sudah tiba." Dan kedua

\footnotetext{
${ }^{12}$ Lugo,Gunche, Manifesto Politik Yesus, (Yogyakarta: Andi, 2009), hlm. 42-43.

${ }^{13}$ Ronald W. Leigh, Melayani dengan Efektif, (Jakarta: BPK Gunung Mulia, 2007), hlm. 189.
} 
eksperiensial, sembuhkan orang sakit, bangkitkan yang mati, tahirkan yang kusta, dan mengusir setan. Proposisinya tidak berdiri sendiri, ia didukung dengan realitas. ${ }^{14}$ Pelayanan yang dimaksud menggunakan waktu untuk memenuhi kebutuhan baik jasmani maupun rohani. Oleh karena itu, manusia patutlah menjadikan Yesus sebagai contoh dan patutan hidup dalam hal melayani, semangat melayani yang diajarkan Kristus patutlah diejawartakan dalam kehidupan sehari-hari terlebih menjawabi wujud pelayanan di masa pandemi ini yang benar-benar membutuhkan sosok seperti Yesus yang mampu memberikan seluruh hidup-Nya kepada manusia tanpa pamrih dan tanpa takut akan penderitaan maupun penyakit.

\section{Penutup}

Semangat melayani dalam ruang lingkup kristianitas di tengah pandemi ini dapat dicontohi melalui sikap Yesus sebagai pelayan dan pengajar. Hal ini ditunjukkan dari sikap Yesus yang senantiasi melayani tanpa membedakan orang, tanpa takut penyakit yang akan menyerang maka Ia menyembuhkan orang dengan berbagai penyakit, tanpa membedakan jenis kelamin, kaya atau miskin, atau tanpa membedakan apabila murid Yesus maka akan dilayani sedangkan apabila bukan tidak akan dilayani. Jadi, meneladani sikap Kristus dengan semangat pelayan perlu diaplikasikan di tengah situasi pandemi.

\section{Daftar Kepustakaan}

Abineno, J.L Ch. 2006. Pedoman Praktis Untuk Pelayanan Pastoral. Jakarta: BPK Gunung Mulia.

Berkhof Louis. 1997. Teologi Sistematika V (Doktrin Gereja). Surabaya: Momentum.

Brown, Franscis. 1998. Interlinear Yunani-Indonesia. Jakarta: Lembaga Alkitab Indonesia.

Darmawijaya, St. 1991. Gelar-gelar Yesus, Yogyakarta: Kanisius.

Depdikbud. 2018. Kamus Besar Bahasa Indonesia (Edisi 5). Jakarta: CV. Adi Perkasa.

Guthrie Donald. 2009. Teologi Perjanjian Baru 1: Allah, Manusia, Kristus. Jakarta: BPK Gunung Mulia.

Leigh, Ronald W. 2007. Melayani dengan Efektif. Jakarta: BPK Gunung Mulia.

Leks, Stefan. 2007. Tafsir Injil Markus. Yogyakarta: Kalam Hidup.

Lugo, Gunche. 2009. Manifesto Politik Yesus. Yogyakarta: Penerbit ANDI.

Maggay, Melda Padilla. 2004. Transformasi Masyarakat. Jakarta: Cultivate Publishing.

Moleong, Lexy. J. 2018. Metodologi Penelitian Kualitatif. Bandung: PT Remaja Rosdakarya.

Nelson, Alan E. 2007. Spirituality \& Leadership. Bandung: Yayasan Kalam Hidup.

Robert R. Boehlke. 2001. Siapakah Yesus Sebenarnya. Jakarta: BPK Gunung Mulia.

Sudarwan. 2002. Menjadi Peneliti Kualitatif Rancangan Metodologi, Presentasi, dan Publikasi Hasil Penelitian untuk Mahasiswa dan Penelitian Pemula Bidang Ilmu Sosial, Pendidikan, dan Humaniora. Bandung: Remaja Rosdakarya.

Syukur Nico. 1987. Kristologi Sebuah Sketsa. Yogyakarta: Kanisius.

\footnotetext{
${ }^{14}$ Maggay, Melda Padilla, Transformasi Masyarakat, (Jakarta: Cultivate Publishing, 2004), hlm. 16.
} 